\title{
OpenStreetMap used in protected area management. The example of the recrea- tional infrastructure in Berchtesgaden National Park
}

\author{
Sabine Hennig \\ Keywords: collaborative mapping, crowdsourcing, community-based data, participatory approaches, visitor management
}

\section{Abstract}

The availability of spatial data is a key concern in protected area management, including visitor management. Obtaining spatial data is often laborious and expensive. New approaches involving the general public in data collection can provide a solution. Among existing crowdsourcing initiatives, OpenStreetMap (OSM) is the largest. But, while public participation geographic information systems (PPGIS), volunteered geographic information (VGI), and user-generated content (UGC) are used in visitor management, OSM still receives less attention.

In this paper, questions regarding the possibilities of using OSM data in visitor management are discussed. The focus is on recreational infrastructure data, since infrastructure is an important means for guiding and managing visitors. The Berchtesgaden National Park (Germany) served as the study area. A list of the relevant elements of the recreational infrastructure in the protected area was elaborated, and an analysis was carried out to determine how useful the OSM tagging system is for describing these elements. In addition, data held in the OSM database was assessed first with regard to which infrastructure elements the OSM database holds data for, and second for the amount of data held. Along with the benefits, there are also challenges in using OSM. Thus, there is a need to expand the OSM tagging system to allow the description of different types of nature-based recreational infrastructure and to increase people's involvement in OSM.
Profile

Protected area

Berchtesgaden

National Park

Mountain range

Alps

Country

\section{Germany}

\section{Introduction}

Relevance of data on recreational infrastructure

Protected areas attract people because of their natural setting and scenic beauty. They are considered outstanding destinations for recreational purposes (Lupp et al. 2016). For most types of protected areas such as national parks, natural monuments / features, and protected landscapes, nature-based tourism and recreational use are primary management objectives. Management needs to facilitate public access for recreational purposes as long as it does not adversely affect the natural environment (IUCN 2008). Hence, protected area management must meet the demands of nature conservation and recreational use at the same time (Zelenka \& Kaceti 2013).

To achieve this, a crucial sub-domain of protected area management is visitor management (van den Berg et al. 2004). Following Candrea and Ispas (2009), Newsome et al. (2001), and Zelenka and Kaceti (2013), visitor management objectives are

1. to protect and improve natural resources in the context of visitor use (attain appropriate and equitable visitor distribution across a territory, optimize visitor flows, keep visitors away from environmentally sensitive areas, communicate minimum-impact behaviour etc.);

2. to increase visitor enjoyment (develop high-quality visitor experience etc.);
3. to maintain and enhance the economic benefits that recreation has on a region.

Various strategies are applied to reach these goals. They can be classified into two categories: first, hard or restrictive actions such as prohibitions, limited access, and entrance fees; second, soft actions based on infrastructure, environmental education, and nature interpretation elements designed to guide, inform and sensitize visitors (Elands et al. 2014; Hennig \& Künzl 2016).

The use of infrastructure in visitor management is considered a promising measure, since infrastructure fulfills different functions (Elands et al. 2014; Worboys et al. 2005). Man-made infrastructure such as carparks, trails and signposting enable recreational visits, and it is necessary to supply such infrastructure. Other elements of infrastructure, such as natural attractions and visitor centres, are attractive destinations. But visitors can also be managed through man-made infrastructure, depending on how it is implemented, and on whether natural attractions are made accessible.

Making decisions on infrastructure (i. e. supply and design) requires an accurate picture of the elements available in the area of interest. High-quality data is an important basis for many aspects of protected area management and, thus, for visitor management. In particular, the availability of spatial data can lead to better decision-making, since spatial data allows 


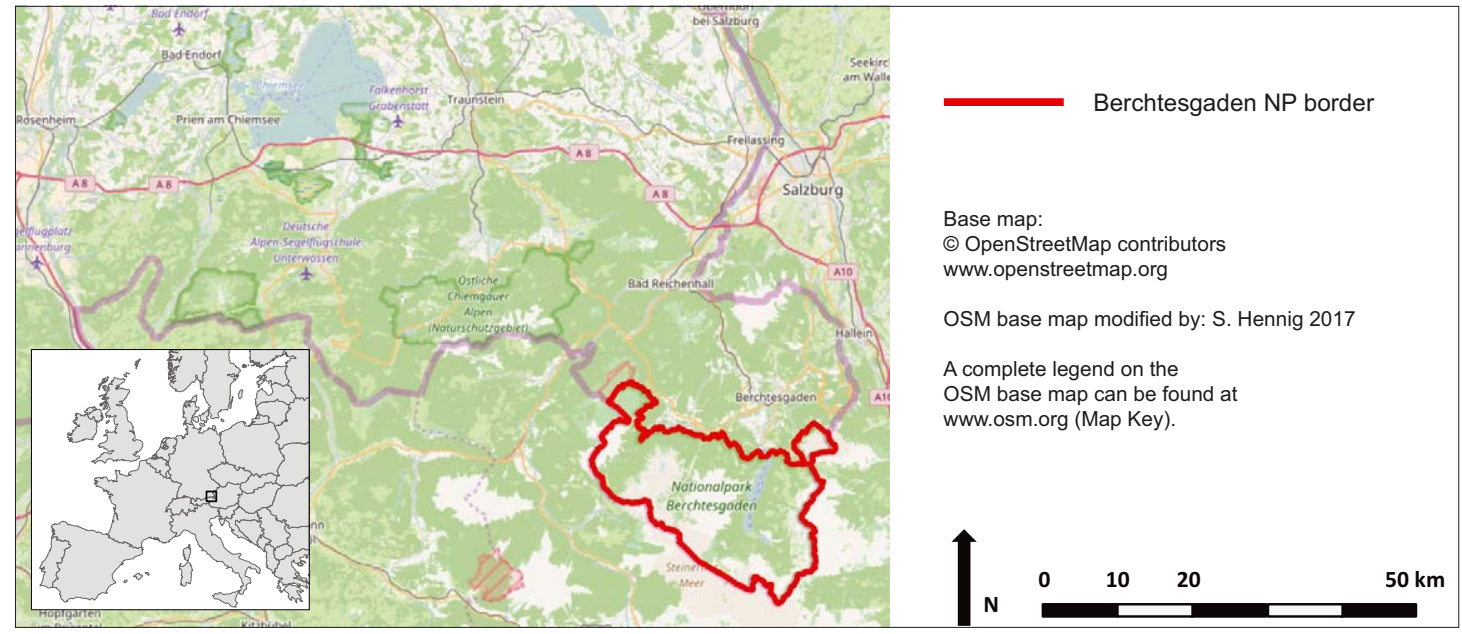

Figure 1 - Location of the Berchtesgaden NP $\left(47^{\circ} 38^{\prime} \mathrm{N}, 13^{\circ} 0^{\prime} \mathrm{E}\right)$.

for the use of geographic information systems (GIS), the application of spatial analysis methods, and cartographic visualization (Worboys et al. 2005).

The provision of spatial data is often related to high workloads and costs. This is true for data on recreational infrastructure. On the one hand, collecting data on-site is laborious and staff-intensive due to such things as the size and accessibility of protected areas, the large number of different infrastructure elements that are related to nature-based recreational activities (trekking, hiking, biking, skiing, snow shoeing, paragliding, etc.), and the fact that third parties (other than the protected area administration) sometimes also have infrastructure in place. On the other hand, acquiring data from external sources can be expensive.

\section{New data sources: community-based data}

Collaborative mapping and crowdsourcing, which involve the general public in data collection, open up new possibilities in helping to close existing data gaps. In many domains, crowdsourced spatial data is seen as an alternative method for obtaining and maintaining authoritative data (Herfort et al. 2015). Among existing initiatives, OpenStreetMap (OSM; Box 1) is the world's largest public collection of spatial data. OSM data is used for a number of purposes, including urban and transportation planning. A large number of third-party services such as navigation systems are built on OSM data (Loidl et al. 2014; OSM ${ }^{1}$ ).

Community-based data presents many benefits: the data is free and up to date, and provides insight into people's perception, knowledge and demands. But several challenges are also discussed in the literature, such as the implementation of suitable strategies to motivate citizens to contribute data, the provision of appropriate data-collection protocols (including e.g. information on ecologically sensitive areas, and citizens' safety while they are mapping elements), data quality control processes, and comprehensive approaches on personal data protection (see, e.g., Brown \& Kyttä 2014; Brown \& Weber 2011; Engels 2015; Lupp et al. 2016; Walden-Schreiner \& Leung 2016).

Crowdsourced data is gaining interest also among protected area and recreational area managers. Related participatory approaches such as public participation geographic information systems (PPGIS), user-generated content (UGC), and volunteered geographic information (VGI) are, for instance, used in protected area management (see, e.g., Brown \& Kyttä 2014). These approaches are presented in Table 1. However, among existing initiatives OSM has so far received rather less attention from protected area and visitor managers.

Table 1 - Background on selected community-based data collection approaches (based on Brown \& Weber 2011; Elwood et al. 2012; OECD 2007).

\begin{tabular}{|l|l|l|}
\hline & Description & Examples of Tools \\
\hline $\begin{array}{l}\text { Public Participation Geographic } \\
\text { Information Systems (PPGIS) }\end{array}$ & $\begin{array}{l}\text { PPGIS refers to different digital and web-based } \\
\text { methods and technologies which allow the cap- } \\
\text { ture, analysis and use of spatial data to support } \\
\text { participatory planning processes. }\end{array}$ & $\begin{array}{l}\text { Off-the-shelf tools: ArcGIS online, CartoDB; } \\
\text { MapBox etc. } \\
\text { Tools requiring own coding: Google Maps, Open- } \\
\text { Layers, Leaflet etc. }\end{array}$ \\
\hline User Generated Content (UGC) & $\begin{array}{l}\text { UGC is created by users who publish their own } \\
\text { content in a digital form, generally on the Internet. } \\
\text { Examples are videos, blogs, discussion forum } \\
\text { postings, images and photos, maps, audio files, } \\
\text { public art, etc. }\end{array}$ & $\begin{array}{l}\text { Social Media and Networking Tools: Facebook, } \\
\text { Twitter, Instagram, Foursquare, Google Photos, } \\
\text { Flickr etc. }\end{array}$ \\
\hline $\begin{array}{l}\text { Volunteered Geographic Informa- } \\
\text { tion (VGI) }\end{array}$ & $\begin{array}{l}\text { VGI (a type of UGC) refers to spatial data that is } \\
\text { either contributed or voluntarily made available, } \\
\text { with an aim to provide data about the world. }\end{array}$ & $\begin{array}{l}\text { OpenStreetMap, Google Map Maker, WikiMapia } \\
\text { etc. }\end{array}$ \\
\hline
\end{tabular}


Box 1 - Background on OpenStreetMap (OSM)

Haklay 2010; Herfort et al. 2015; Loidl et al. 2014; Loidl \& Keller 2015; Quinn \& Dutton 2014; OSM

OSM (www.openstreetmap.org) is an online open data platform for the collection of the world's geographic data. It is based on the Wikipedia model of crowdsourcing. Since launching in 2004, the number of registered users and active contributors has been steadily increasing. Current OSM statistics show 2.9 million registered users; the number of unregistered users is many times higher. The result of this collaborative project is a free, editable (living) map of the world created by the citizens at a level of detail that is unparalleled in human history. Aside from the map itself, the data generated is considered its primary output: the data, which is available free of charge under the Open Database License (ODbL), can be downloaded and used free of charge for all kinds of purposes, including commercial ones.

There are three main ways to add data to OSM: (1) collecting data from scratch by performing systematic ground surveys (using e. g. GPS-enabled mobile devices, handheld GPS units), (2) satellite imagery tracing, and (3) importing existing datasets. To store data, OSM uses a topological data structure with three types of data elements:

- Nodes

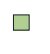

- Ways

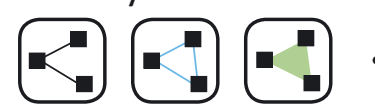

- Relations
- points with a geographic position stored as coordinates (latitude and longitude) according to WGS 84;

- used to represent map features without a specific size, such as points of interest, or to generate ways;

- ordered lists of nodes, representing a polyline, or a polygon if they form a closed loop;

used to represent linear features such as streets and rivers, and boundaries of areas like forests, parks, parking areas, and lakes;

- ordered lists of nodes, ways and other relations;

- $\quad$ used to represent the relationships of existing nodes and ways (e. g. turning restrictions on roads, routes that span several existing ways such as long-distance motorways, and areas with holes) (e.g. lake with an island).

Specific features of a data element (nodes, ways and relations) are described using tags. Each tag consists of a key and a value (form key=value; e. g. amenity=parking). The OSM community agrees on certain key and value combinations regarding tags. These serve as informal standards. So-called primary tags are used to describe what the feature is. They define the feature type. Additional, i. e. optional tags (secondary tags), describe further properties (for example, primary tag: amenity=parking; secondary tag: capacity=200). Since OSM uses a free tagging system, this allows the map/database to include an unlimited number of attributes to describe features. Users can assign as many tags as they like to features. If more tags are assigned, there is more information on the feature. Since users can choose any tag, different attributes might exist for the same type of feature (so-called attributive heterogeneity). This provides challenges regarding analysis and further use of the data. It is one of the main differences from commercial and government databases, which usually rely on a determined data structure.

The main copy of the OSM data is stored in a PostgreSQL database. It has one table for each data primitive (nodes, ways, and relations), with individual objects stored as rows. All editing occurs in this database. For data transfer, database dumps (planet.osm) are created, which can be downloaded in two file formats, XML or PBF.

Aims

For many domains, community-based data and in particular OSM data are seen as promising means to fill existing (spatial) data gaps. Nevertheless, there is still a lack of studies evaluating the extent to which OSM data is useful for meeting the needs of specific decision makers effectively (Herfort et al. 2015). This also refers to the use of OSM data in visitor management focusing on recreational infrastructure. Here, in particular, the following questions need to be answered: Can OSM data be considered a valuable source of spatial data on recreational infrastructure?
What are the benefits and challenges of using OSM data in visitor management?

In this paper, these questions are discussed based on the analysis of OSM infrastructure data related to recreational use in the Berchtesgaden National Park (NP) in Germany. The OSM tagging system is examined with regards to its usefulness, and the OSM database is assessed for the amount of data it provides, and for which infrastructure elements data is held. Throughout, one of the main requirements of collaborative projects was kept in mind: not only to benefit from community input, but also to give something back to the community and/or to give some 


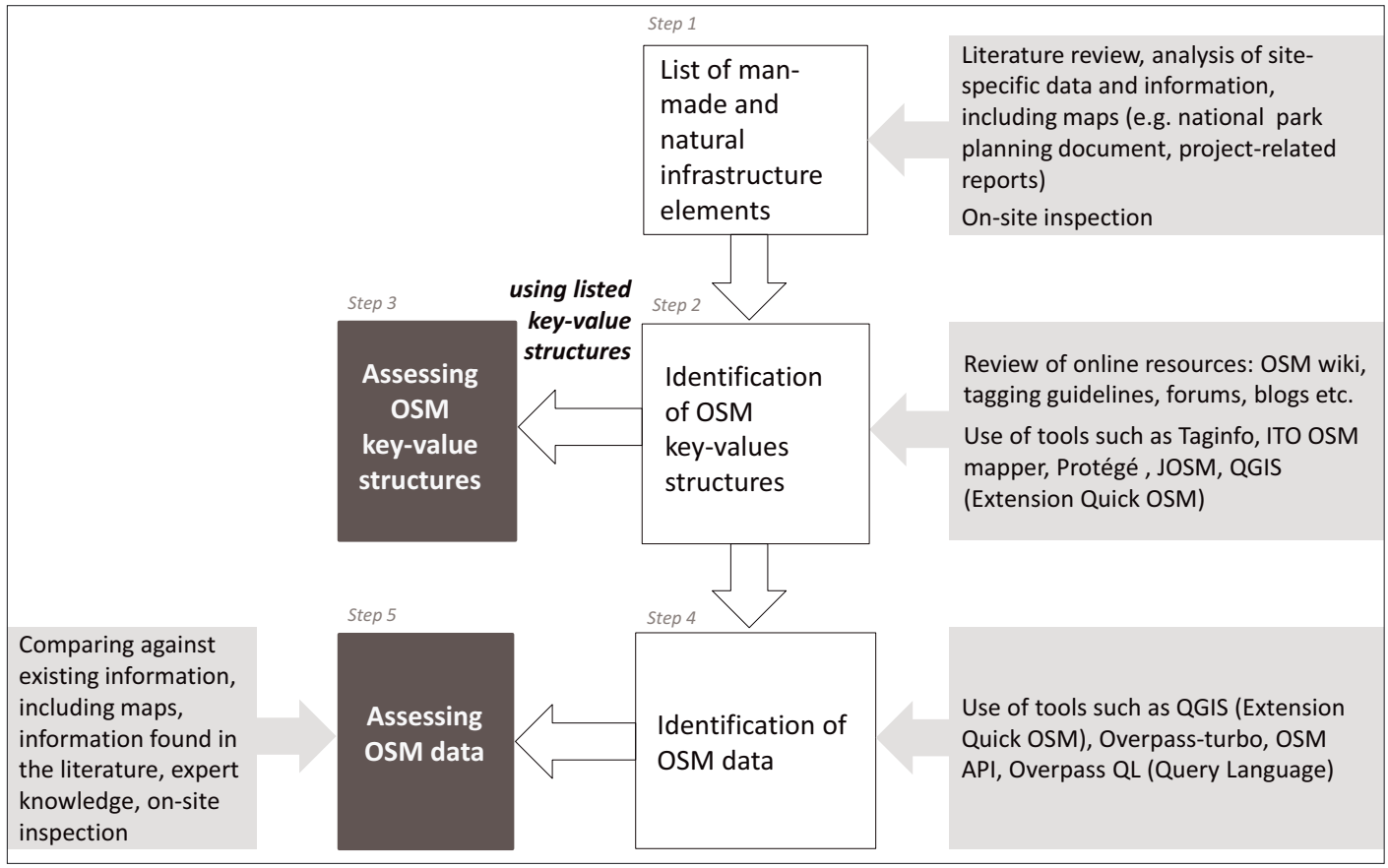

Figure 2 - Workflow applied to assess OSM (tagging system and database) regarding infrastructure related to recreational use in the Berchtesgaden NP.

recognition of the contribution made (CEAA 2016; Coleman et al. 2009). Several studies have already been conducted on the spatial accuracy of OSM data and show that the data quality is in many cases comparable to official or commercial data sets (Haklay 2010), so spatial accuracy was not focused on in this study.

\section{Study area Berchtesgaden NP}

The Berchtesgaden NP is situated in South-East Germany along the border with Austria, $30 \mathrm{~km}$ south of the Austrian city of Salzburg (Figure 1; $47^{\circ} 38^{\prime} \mathrm{N}$, $\left.13^{\circ} 0^{\prime} \mathrm{E}\right)$. It covers an area of $210 \mathrm{~km}^{2}$ at an elevation ranging from $600 \mathrm{~m}$ a.m.s.l. (Lake Königssee) to $2700 \mathrm{~m}$ a.m.s.l. (Watzmann Massif). Berchtesgaden NP, which was established in 1978, is the only German NP in the Alps and it is part of the Northern Limestone Alps. The main management objectives in the park are nature conservation, environmental education, providing the public with requirements for recreation, and scientific research (BayStMLU 2001).

Tourism and recreational use have a long tradition in the region, which is one of the oldest holiday destinations in the Alps. To this day tourism and recreational use play a pivotal role in the region, and the NP is one of its main attractions. The annual number of visitors to the NP is over 1.2 million. The vast majority of visitors come between May and October, for recreational activities such as walking, hiking, climbing, cycling, mountain-biking, sledging and ski-touring (BayStMLU 2001; Job et al. 2003).

\section{Approach, methods and tools used}

The analysis and assessment of the usefulness of the OSM tagging system and OSM database regarding recreational infrastructure as a means in visitor management relied on a five-step process (Figure 2). It began with an analysis of the information requirements in the area of visitor management concerning recreational infrastructure; it went on to evaluate whether these requirements were met.

1. Preparation of a list of man-made and natural infrastructure elements important for nature-based recreation in the Berchtesgaden NP.

2. Identification of OSM tags (i.e. key-value structures) useful in describing the infrastructure elements which have been identified in step one.

3. Assessment of the usefulness of the OSM tagging system (the OSM key-value structures identified) to describe infrastructure.

4. Identification of data on recreational infrastructure held in the OSM database using the key-value structures provided in step 2.

5. Assessment of the identified OSM data by comparing it to a selection of existing data and information.

Since all work was carried out before the end of summer 2016, the results are based on OSM tags and data that were available in OSM at that time. Various tools and information sources - as presented in Figure 2 - were used. The most important sources were the information presented in the NP planning document (BayStMLU 2001) and elaborated on by the project Monitoring of recreational use in the transboundary recreation area Berchtesgaden NP/Salzburg Kalkhochalpen 
Table 2 - Existence of usefulness of OSM tags to name recreational infrastructure.

\begin{tabular}{|c|c|c|c|}
\hline \multicolumn{2}{|c|}{$\begin{array}{l}\text { Categories \& } \\
\text { types of infrastructure }\end{array}$} & \multirow{2}{*}{\begin{tabular}{|l|}
$\begin{array}{l}\text { Usefulness } \\
\text { of OSM tags }\end{array}$ \\
yes \\
\end{tabular}} & \multirow{2}{*}{\begin{tabular}{|l|}
$\begin{array}{l}\text { Primary tags available to ad } \\
\text { dress features }\end{array}$ \\
amenity \\
\end{tabular}} \\
\hline \multirow{4}{*}{ 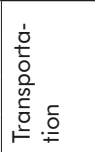 } & Carpark & & \\
\hline & Bus station & yes & amenity, public transportation \\
\hline & Ferry stop & yes & amenity, public transportation \\
\hline & Cable car station & yes & aerial way, public transportation \\
\hline \multirow{6}{*}{ 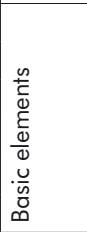 } & Bench & yes & amenity \\
\hline & Picnic site & yes & leisure, tourism \\
\hline & Shelter & yes & amenity \\
\hline & Viewpoint & yes & tourism \\
\hline & Drinking water & yes & amenity, spring \\
\hline & Playground & yes & leisure \\
\hline \multirow{2}{*}{ 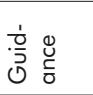 } & Guidepost & yes & information \\
\hline & Route marker/trail blaze & yes & information \\
\hline \multirow{7}{*}{ 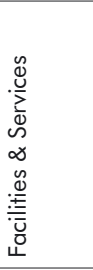 } & Alpine hut & yes & tourism \\
\hline & Restaurant & yes & amenity \\
\hline & Alm hut & not fully & tourism, amenity \\
\hline & Kiosk & yes & shop \\
\hline & Toilet & yes & amenity \\
\hline & Telephone & yes & amenity \\
\hline & Emergency phone & yes & amenity, emergency \\
\hline \multirow{9}{*}{ 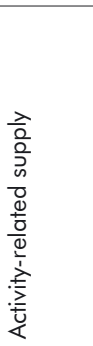 } & Hiking trail & yes & route, highway \\
\hline & Climbing site & yes & sport \\
\hline & Swimming site & yes & sport, natural, leisure \\
\hline & Rowing site & yes & sport \\
\hline & Cycling trail & yes & route, highway \\
\hline & Ski-mountaineering route & yes & route, piste \\
\hline & Sledging route & yes & route, piste \\
\hline & Snowshoe route & yes & route, piste \\
\hline & Free-flying/paragliding site & yes & sport \\
\hline \multirow{8}{*}{ 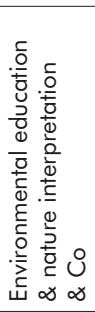 } & National park visitor centre & not fully & tourism, information \\
\hline & Information board/map & yes & information \\
\hline & Wildlife observation site & yes & leisure \\
\hline & Wildlife observation tower & not fully & man_made \\
\hline & Suspension bridge & not fully & building \\
\hline & Nature experience element & missing & - \\
\hline & Educational trail & missing & - \\
\hline & Land/natural art & not fully & tourism \\
\hline \multirow{4}{*}{ 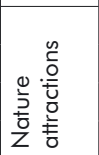 } & Peak & yes & natural \\
\hline & Cascade/waterfall & yes & natural \\
\hline & Spring & yes & natural \\
\hline & Cave entrance & yes & natural \\
\hline
\end{tabular}

(2004-2008; see, e.g., Nationalpark Berchtesgaden 2007), hereafter referred to as Monitoring Project.

\section{Results}

\section{OSM tagging system}

A wide range of recreational infrastructure types can be found in the Berchtesgaden NP. The different elements can be divided into seven categories (Table 2): (1) transportation \& mobility, (2) basic elements, (3) orientation \& navigation, (4) facilities \& services, (5) natural attractions, (6) activity-related elements, (7) environmental education $\&$ nature interpretation.

OSM provides a multitude of tags to describe data on nature-based recreational infrastructure, thus al- lowing the majority of elements relevant to recreation in the Berchtesgaden NP to be described (Table 2). However, there are some challenges and gaps:

- No primary tags exist that focus exclusively on nature-based recreation. As a result, tags related to areas such as leisure, nature, tourism and sport were used to name the recreational infrastructure.

Two different approaches are taken in order to describe features. First, the type of infrastructure is identified (e.g. carpark, bench, alpine hut). Keys used include amenity, highway, leisure, nature, public transportation and tourism. Second, the sport or activity that may be performed there is used to describe the element or site. This approach is used to tag features that are of interest for specific naturebased activities, mainly not trail-related ones. Examples, therefore, are sites for swimming, climbing or paragliding (e.g. sport=swimming, sport=climbing, sport=paragliding).

Depending on the element, it is described by (1) primary tags, (2) secondary tags, or (3) a combination of tags (Table 3). There are thus a number of different possibilities to name a feature. This is specific to crowdsourced data, and unlike authoritative data, which usually follows strict specifications (Loidl et al. 2014). Thus, for instance, to tag trails, routes or slopes - key elements for nature-based recreation activities such as hiking, biking and skiing - different possibilities exist (Table 4): e. g. primary keys like route, highway or piste (term used by the OSM tagging system for slopes), or secondary tags such as foot $=$ yes, bicycle $=$ yes or snowshoe $=$ yes.

- Not all types of infrastructure can be appropriately described by OSM tags. No tags exist to describe certain environmental education and nature interpretation / experience elements. Examples are educational trails, land / natural art, or features such as a tree telephone or barefoot path.

\section{OSM database}

Even though the OSM tagging system allows the description of most recreational infrastructure elements in the Berchtesgaden NP, the OSM database does not hold data on all infrastructure types and elements found there (Table 5). The situation can be described as follows:

Infrastructure related to transportation and mobility is well represented in OSM (bus and ferry stops, cable car stations etc.). The same is true for e. g. hiking and biking trails, benches, shelters, alpine huts, restaurants, alpine pastures with cabins where food and drinks are provided (Alm huts), playgrounds, NP information centres, and peaks. These are mostly elements for which authoritative data (e.g., NP planning document) or project-related data (e. g., Monitoring Project) also exists.

- Some OSM data is available regarding guideposts drinking water, picnic sites, viewpoints, information boards / maps, and ski-tour routes. Data re- 
garding these elements is also provided by various projects (Monitoring Project; Preuss 2005 etc.).

- Only limited OSM data exists concerning climbing and swimming sites, toilets and kiosks. While authoritative and project-related data exist for the activity-related elements, only sparse authoritative and project-related data is found regarding the facilities.

- No OSM data is found for particular elements concerning environmental education, or nature interpretation / experience (e. g. geological interpretative trail, nature experience area), for many activityrelated sites (except hiking and cycling / mountainbiking), or natural attractions (except peaks and cave entrances). Authoritative and project-related data presents elements and sites related to recreational sports activities, environment education and natural attractions. Less data is available on nature interpretation / experience elements.

\section{Discussion: benefits and challenges of us- ing OSM}

\section{Benefits of using OSM}

At first glance, OSM data available on recreational infrastructure in the Berchtesgaden NP seems to lag behind other sources. The OSM data pertains mostly to elements on which authoritative and project-related data also exists. This is in line with findings that outline that OSM data on urban areas is not inferior to administrative or commercial data (Loidl et al. 2014). Nevertheless, the situation looks different for rural and natural sites.

Despite this - and in addition to the benefits generally assigned to the use of OSM data (Box 1) - there are advantages which make OSM a valuable data source for visitor management. Many of these advantages are also important for the visitors: armed with additional data, visitor managers are able to better meet visitor needs and demands regarding recreational infrastructure, and so visitor experience may be enhanced.

\section{Flexibility and up-to-dateness}

Due to a large community of users, the OSM database is or can easily be updated promptly in the event of new infrastructure being implemented or existing elements being changed. This is in contrast to commercial and authoritative databases, which are usually updated at fixed intervals, or project-related data, which is collected only once (Quinn \& Dutton 2014).

Thus, for instance, data on benches is continually being added to OSM. About $50 \%$ of the OSM data on benches found in Berchtesgaden NP (139 features) has been collected since 2014, with the first bench having been mapped in 2009. Figure 3 provides information on the number and distribution of benches located in Klausbach Valley mapped in OSM. Benches are an important infrastructure for the elderly and mobilityimpaired visitors who come for a walk. Following Bell
Table 3 - Examples of tagging features using primary and secondary tags, and tag combinations

\begin{tabular}{|l|l|}
\hline Tagging options & Examples (element à "key=value") \\
\hline Use of primary tags & $\begin{array}{l}\text { - parking à amenity=parking } \\
\text { - picnic site à tourism=picnic_site } \\
\text { - viewpoint à tourism=view_point }\end{array}$ \\
\hline Use of secondary tags & $\begin{array}{l}\text { - information board à information=board } \\
\text { - route marks à information=route_marker } \\
\text { - trail blazing à information=trail_blaze }\end{array}$ \\
\hline $\begin{array}{l}\text { Use of tag combina- } \\
\text { tions }\end{array}$ & $\begin{array}{l}\text { - observation tower à man_made=tower; Tower: } \\
\text { Type=observation }\end{array}$ \\
& $\begin{array}{l}\text { information board with environmental educa- } \\
\text { tion content à information=board; board_ } \\
\text { type=geology/board_type=nature / board__ } \\
\text { type=plants / board_type=wildlife }\end{array}$ \\
\hline
\end{tabular}

(2007), they should be placed at suitable intervals (e.g. every $100 \mathrm{~m}$ ), in attractive locations, and fulfil certain characteristics, such as providing a backrest (OSM tag backrest=yes).

\section{Problems with administrative boundaries}

Authoritative data usually refers only to the area of responsibility of an administrative body. But elements of interest are often also located in areas crossing administrative boundaries. For instance, some ski-tour routes go through adjoining administrative areas. Consequently, visitors also rely on infrastructure outside the protected area (Hennig \& Pfeifer 2011). Accordingly, managers need to know about this infrastructure, which has a strong influence on the number and types of visitors. Since OSM is a globally-oriented project and does not take administrative boundaries into consideration (Loidl et al. 2014), it addresses the demand for seamless data.

With regard to the Berchtesgaden NP, several elements relevant for visitors are located outside the park area. These include transport infrastructure (carparks,

Table 4 - Examples for naming trails and related features regarding different activities

\begin{tabular}{|c|c|}
\hline Activity & Tag naming the trail \\
\hline $\begin{array}{l}\text { Going for a } \\
\text { walk }\end{array}$ & $\begin{array}{l}\text { - Route=foot (primary key) } \\
\text { - Highway= path (primary key) } \\
\text { - Highway=footway (primary key) } \\
\text { - Sac_scale=walking (secondary key) }\end{array}$ \\
\hline Hiking & $\begin{array}{l}\text { - Route=hiking (primary key) } \\
\text { - Highway=path (primary key) } \\
\text { - Highway=footway (primary key) } \\
\text { - Highway=track (primary key) } \\
\text { - Foot=yes/designated (secondary key) } \\
\text { - sac_scale=hiking/mountain_hiking/demanding_mountain_- } \\
\text { hiking/alpine_hiking/demanding_alpine_hiking/difficult_al- } \\
\text { pine_hiking (secondary key) } \\
\text { - Piste: type=skitour (secondary key) }\end{array}$ \\
\hline $\begin{array}{l}\text { Cycling/moun- } \\
\text { tain biking }\end{array}$ & $\begin{array}{l}\text { - } \text { route }=\text { mtb (primary key) } \\
\text { - route }=\text { bicycle (primary key) } \\
\text { - highway }=\text { cycleway (primary key) } \\
\text { - } \text { highway=track (primary key) } \\
\text { - } \text { bicycle=yes / designated (secondary key) }\end{array}$ \\
\hline $\begin{array}{l}\text { Ski } \\
\text { mountaineering }\end{array}$ & $\begin{array}{l}\text { - Route=skitour (primary key) } \\
\text { - Route=ski (primary key) } \\
\text { - Piste: type=skitour (secondary key) }\end{array}$ \\
\hline Snowshoeing & $\begin{array}{l}\text { - Route=snowshoe (primary key) } \\
\text { - Snowshoe=yes / designated (secondary key) } \\
\text { - Piste: grooming=backcountry }\end{array}$ \\
\hline
\end{tabular}




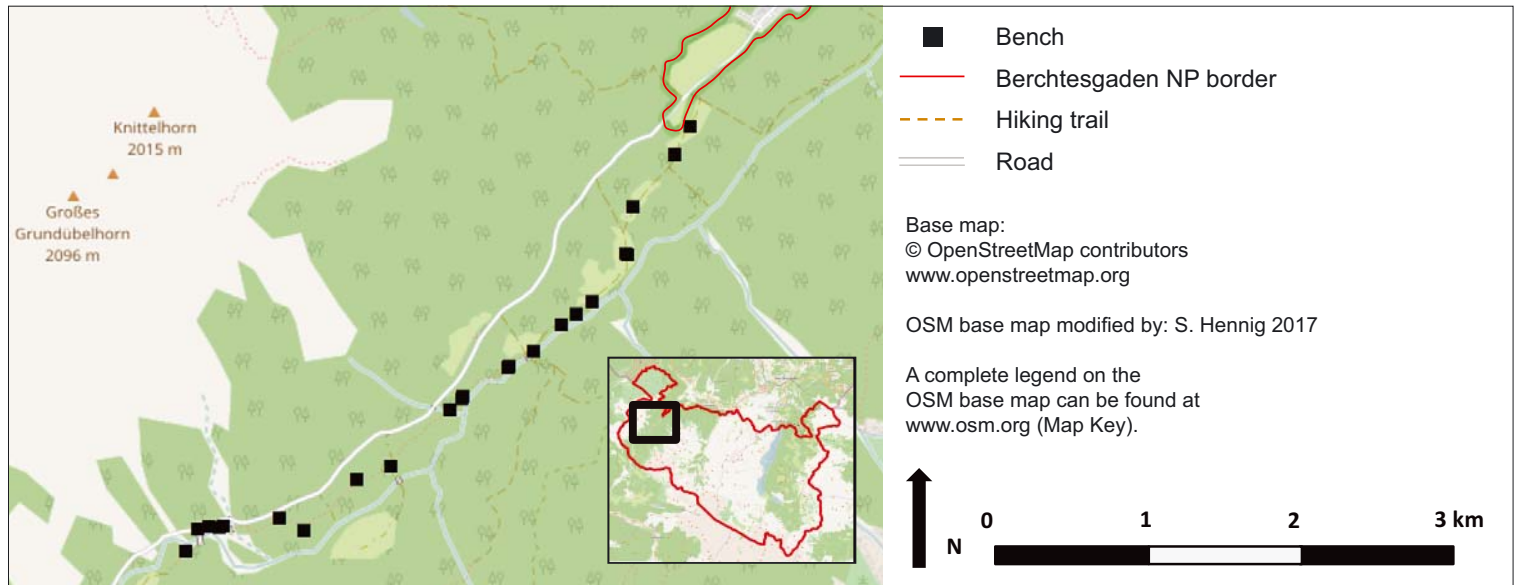

Figure 3 - Benches located in Klausbach Valley, mapped in OSM.

bus stops, cable car stations, etc.), NP information centres, alpine huts, as well as hiking, biking, and skimountaineering trails. Particularly ski-mountaineering tours not only start outside the park area, but also take recreationalists outside the NP several times (Figure 4). Therefore, the results presented in Table 5 focus on the park area and adjoining areas.

\section{Visitor usage and presence}

Visitors, in particular local people, also use infrastructure not assigned for recreational use (e.g. old or non-official trails). These features and their use might not be known to managers. Relevant data is often missing (Lupp et al. 2016). Moreover, some nature-based recreational activities, such as ski-mountaineering and snow-shoeing, do not rely on man-made infrastructure. To perform these activities, visitors rely on certain conditions in the natural environment such as the topography, steepness and vegetation (BfN). Having visitors track their activities and / or tours using GPS and adding this data to OSM allows managers to gain insights into where people really go and how they move within an area (Monteiro 2016). Visitors thus create spatial data on aspects which are otherwise difficult to capture.

\section{Visitor perspective}

Users' freedom to add data on features as they please and describe them using an unlimited number of different attributes (tags) is one advantage of OSM (Box 1). This may result in a more comprehensive set of data compared to administrative databases. Even though this freedom poses a challenge for data processing and analysis, it delivers added value for visitor management and consequently for visitors (e.g. more suitable infrastructure). One benefit is the insight given into people's individual points of view and perceptions, and local knowledge (Herfort et al. 2015; Quinn \& Dutton 2014). Such information is usually gathered by empirical social science research methods such as questionnaires, interviews and observation. As outlined by Brown and Weber (2011), the use of crowdsourced initiatives (e.g. OSM) opens up new ways to collect data on visitors and their needs.

Tags that are particularly helpful for visitor management are: description (general feature description, i. e. additional information about the related element), condition (the state/condition in which the infrastructure is), trail visibility (the trail's direction and how easy it is to see ahead), or wheelchair (indicating

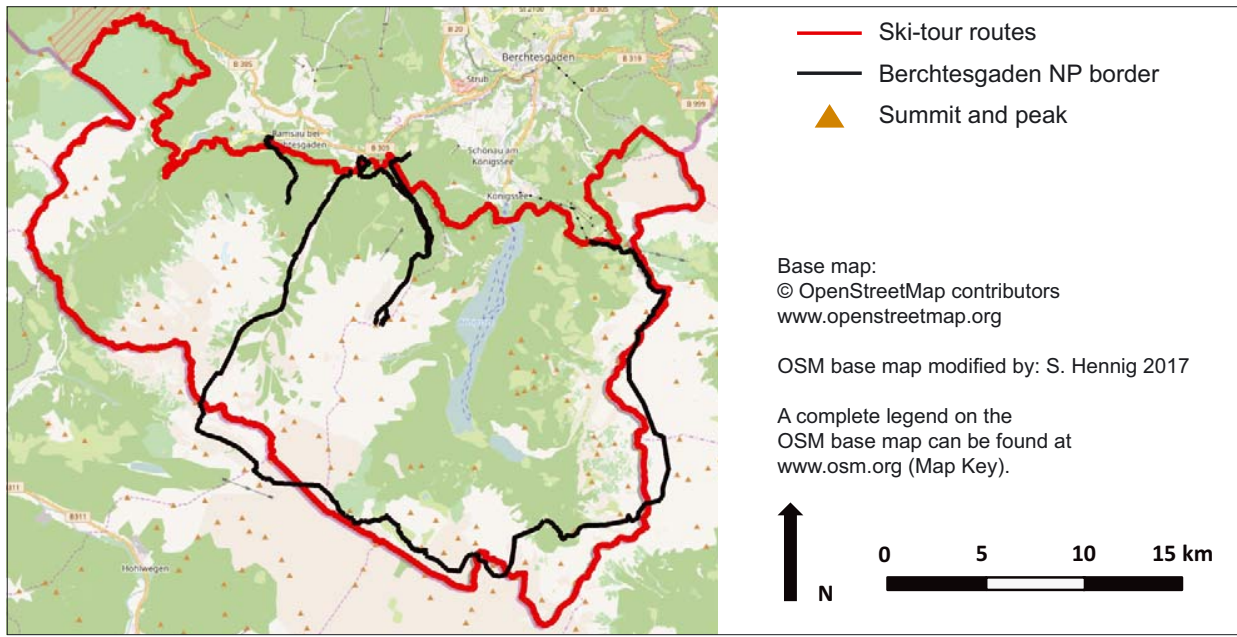

Figure 4 - Selected ski-tour routes in the Berchtesgaden NP, starting outside the park area, crossing NP boundary, mapped in OSM. 
Table 5 - Assessment of OSM infrastructure data relevant for recreational use in the Berchtesgaden NP (taking into consideration adjoining areas). +++ many data (i.e. almost all elements found on-site are mapped); ++ some data; + data on single elements; - no data.

\begin{tabular}{|c|c|c|c|}
\hline Element & $\begin{array}{l}\text { Assessment of amount of OSM } \\
\text { data regarding infrastructure types }\end{array}$ & Element & $\begin{array}{l}\text { Assessment of amount of OSM } \\
\text { data regarding infrastructure } \\
\text { types }\end{array}$ \\
\hline Carparks & +++ & Swimming site & + \\
\hline Ferry stop & +++ & Cycling trail & +++ \\
\hline Cable car station & +++ & Ski-tour route & + \\
\hline Shelter & +++ & Free-flying/paragliding site & - \\
\hline Viewpoint & ++ & National park visitor centre & +++ \\
\hline Drinking water & ++ & Information board/map & ++ \\
\hline Playground & ++ & Wildlife observation site & ++ \\
\hline Toilet & ++ & Land/natural art & - \\
\hline Telephone & - & Peak & +++ \\
\hline Emergency phone & - & Cascade/waterfall & - \\
\hline Hiking trail & +++ & Spring & - \\
\hline Climbing site & + & Cave entrance & +++ \\
\hline
\end{tabular}

whether the place or path is suitable for use with a wheelchair or other mobility device).

Efforts to improve the accessibility of protected areas for disabled people in particular have increased in recent years (see, e.g., Nationalpark Berchtesgaden 2006; Türk \& Wölfel 2016; Wasserburger et al. 2016). Improving disabled access requires data on barrierfree infrastructure in order to support planning and to meet information requirements (Dörrzapf et al. 2015). Visitors' own assessments of whether an element is accessible for mobility-impaired visitors or not (see, e. g., Figure 5) might trigger discussions with managers or planners, whose assessments of accessibility might be radically different. Consultation with mobility-im- paired visitors - based on data provided in OSM - can thus feed into planning new or improved infrastructure elements and contribute to better accessibility of natural sites for disabled people.

\section{Challenges of using OSM}

The benefits outlined above underline the need to extend the OSM tagging system and to increase the amount of data held in the OSM database in line with visitor management needs. This requires encouraging visitors to contribute to OSM, and supporting them in doing this. Further, in order to benefit from OSM, requirements are also placed on protected area and visitor managers.

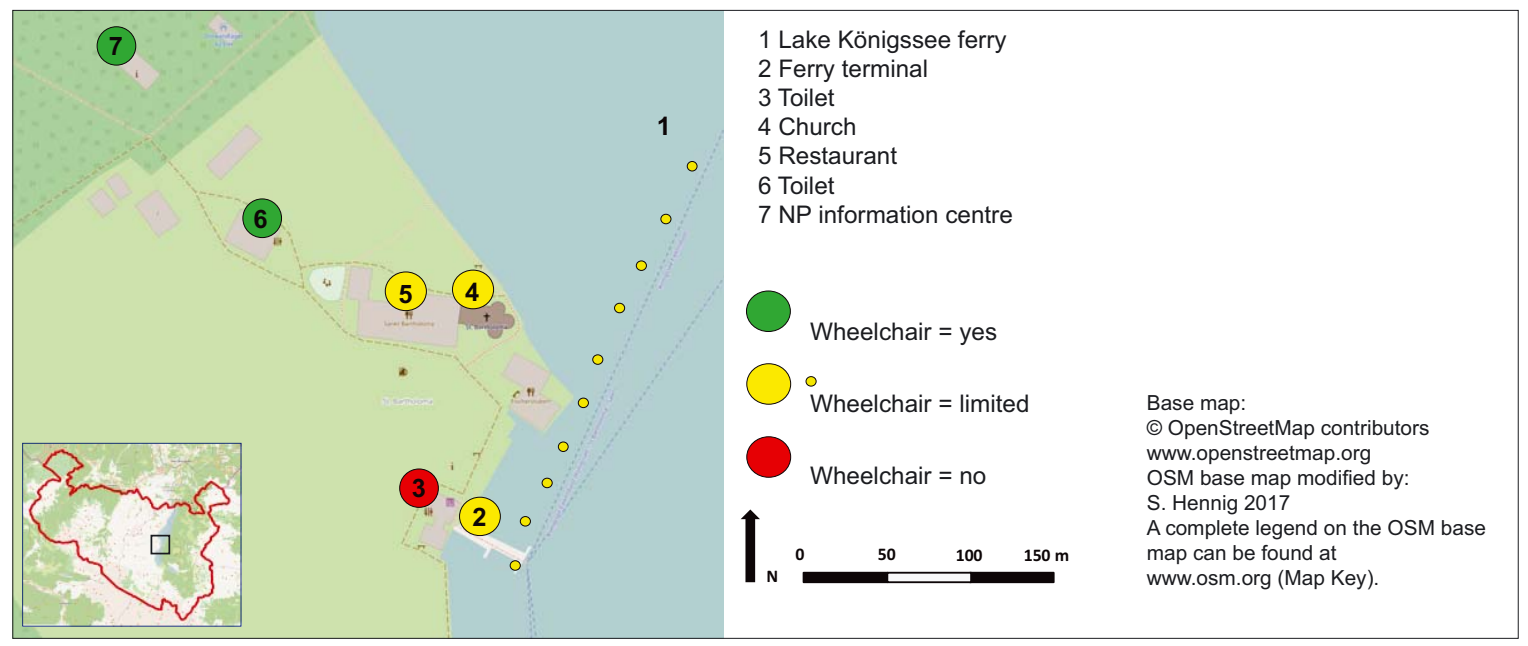

Figure 5 - Features located at St. Bartholomew and mapped in OSM providing information about whether the place or path is suitable to be used with a wheelchair or other mobility device. 
Table 6 - Selection of initiatives and examples to enable and motivate citizens and visitors to contribute to OSM.

\begin{tabular}{|c|c|}
\hline Initiative & Examples and detailed information \\
\hline $\begin{array}{l}\text { Site-specific events / } \\
\text { workshops }\end{array}$ & $\begin{array}{l}\text { Many natural areas offer GPS tracking tours or geocaching events. Guided tours - similar to those - with a focus on } \\
\text { the natural environment and showing participants how to tag and map features in OSM could be provided, allowing } \\
\text { the creation of synergies between data collection needs and environmental education offerings/activities. }\end{array}$ \\
\hline $\begin{array}{l}\text { OSM mapping } \\
\text { parties }\end{array}$ & $\begin{array}{l}\text { OSM mapping parties run in cooperation with the OSM community. They are conducted by experienced users, and } \\
\text { are a common means to encourage and help the general public to contribute to OSM and carry out mapping (see } \\
\text { http://wiki.openstreetmap.org/wiki/Mapping_parties). }\end{array}$ \\
\hline OSM mapathons & $\begin{array}{l}\text { Similar to OSM mapping parties, OSM mapathons can be run. These are coordinated mapping events which are very } \\
\text { often held indoors (armchair mapping), but they can also be conducted outdoors or as a combination of indoor and } \\
\text { outdoor mapping activities (see http://wiki.openstreetmap.org/wiki/Mapathon). }\end{array}$ \\
\hline OSM SommerCamp & $\begin{array}{l}\text { OSM SommerCamps can be hosted. These events last several days and combine social activities, mapping, and } \\
\text { information exchange regarding OSM (see https://wiki.openstreetmap.org/wiki/SommerCamp_2016). }\end{array}$ \\
\hline $\begin{array}{l}\text { Cooperation with } \\
\text { the educational field }\end{array}$ & $\begin{array}{l}\text { Spatial literacy (skills that allow users to make use of spatial data and spatial data tools in a competent and capable } \\
\text { manner) is gaining importance. Relevant skills are imparted through school education, but several initiatives focus } \\
\text { also on building these skills among the general public. Thus, for example, Uni-55 PLUS (University Salzburg) has for } \\
\text { several years been running seminars for people over } 55 \text { to improve their spatial literacy. There is a particular focus } \\
\text { on OSM. As required by the principles of adult education, these courses are highly practical and focus on real-life } \\
\text { problems. Topics for these seminars might be provided by protected areas (see https://www.uni-salzburg.at/fileadmin/ } \\
\text { multimedia/Universitaet\%2055-PLUS/documents/WVZ_WS_16_17_Version_07.09.2016_web.pdf). }\end{array}$ \\
\hline Project participation & $\begin{array}{l}\text { Several scientific projects address open questions regarding the use of OSM by the general public (e.g. https://www. } \\
\text { uni-salzburg.at/index.php?id=206051), and in particular by pupils. Being a partner in such projects opens up many } \\
\text { possibilities to learn about users and/or visitors, to equip users with the necessary skills and motivate them, and to } \\
\text { improve the OSM database regarding the sites concerned. }\end{array}$ \\
\hline Tutorials/material & $\begin{array}{l}\text { Just as geocaching is supported by tutorials and other materials, people contributing to OSM also appreciate help. } \\
\text { Links to online material prepared by the OSM community (e. g. OSM wiki) can be provided, and other material can } \\
\text { be developed by the protected areas and/or natural sites. This allows environmental education topics and visitors' } \\
\text { safety issues etc. to be included. }\end{array}$ \\
\hline Tool provision/links & $\begin{array}{l}\text { Many desktop and mobile applications are available free of charge, allowing the general public to add data to } \\
\text { OSM (e.g. iD 2, JOSM, Vespucci, OSMand). Additionally, increasing numbers of large protected areas (including the } \\
\text { Berchtesgaden National Park) provide mobile apps. Information and links provided in mobile apps can direct users to } \\
\text { tools that enable them to add data to OSM. }\end{array}$ \\
\hline
\end{tabular}

\section{Feature tagging}

Tags must be proposed to the OSM community for features for which there are no tags in the OSM tagging system, or for which the current tags are not sufficiently suitable (e.g. environmental education / nature interpretation elements, land / natural art, Alm huts). The proposal process is described under $\mathrm{OSM}^{2}$. However, proposals must be in line with the general needs of mapping recreational infrastructure: since OSM aims to provide crowdsourced data for the whole world, tag proposals must reflect the concerns not simply of a single site, but of recreational use and areas in general.

Furthermore, to improve feature tagging, information on how to tag elements should be easy to find and understand, and explain which (primary, secondary) tags or tag combinations to use. For example, users apparently face problems when it comes to describing alpine huts. Even though a tag exists to describe these features (tourism=alpine hut), the majority of the huts (six out of nine) are tagged as restaurant, thus highlighting the need to support users with more detailed explanations.

\section{OSM data contribution}

There is a need to enable and motivate visitors to contribute to the OSM database by providing suitable tools and improving their spatial literacy. Selected initiatives are listed in Table 6. Another relevant point in this context is that the benefits which the community derives from contributing to OSM must be made clear for everyone. These might include improvements to the recreational infrastructure and thus visitor experience, and innovative environmental education offerings and activities. For example, people enjoy using mobile devices and geo-media such as online maps (Vogler 2015). As outlined in the case of geocaching, environmental education content can be imparted through the use of information and communication technology (Willis et al. 2014). Visitors can be invited to contribute to OSM by making use of related tools and digital mobile devices. By combining mapping activities with environmental education issues, innovative methods can be created, allowing visitors to experience and enjoy nature in a new and inspiring way.

\section{OSM data use by protected area / visitor managers}

The amount and quality of data is continuously growing, as are the benefits related to the use of OSM data. Protected area and visitor managers should be aware of the possibilities but also of the challenges of OSM. They must understand, for instance, how to check OSM data for quality, and how to carry out preprocessing. Several tools can be used to check the OSM data for potential errors, inaccuracy or sparsely mapped places $\left(\mathrm{OSM}^{3}\right)$. The data extracted from OSM must be processed and transformed so that it is suitable for use in later work (see, e. g., Hennig et al. 2012). Accordingly, staff must be aware of the benefits of using OSM and be skilled in using it. 


\section{Conclusion}

The focus of this paper was the usefulness of OSM regarding recreational infrastructure to support protected area visitor management. Based on the example of the Berchtesgaden NP, results show, first, that even though most infrastructure types can be described by OSM tags, tags to characterize, for instance, environmental education and nature experience/interpretation elements are still missing in the tagging system. Second, in terms of the amount of data available, OSM data on recreational infrastructure in the Berchtesgaden NP seems to lag behind existing authoritative and project-related information.

The benefits of using OSM (free, up to date, absence of boundary problems, provision of data on elements that are hard to collect, insight into people's individual perspectives and perceptions, etc.) underline the need to propose new tags to the OSM community. Further, different approaches to engage and prepare visitors to contribute to OSM must be considered and new approaches should be developed. However, not only must visitors be motivated and competent in how to tag and edit OSM data, but the protected area / visitor managers must also have the necessary competence to use OSM data.

\section{References}

BayStMLU Bayerisches Staatsministerium für Landesentwicklung und Umweltfragen 2001. Nationalparkplan. Berchtesgaden. [In German]

Bell, S. 2007. Accessibility and Disability. Making Woodlands more accessible. Open Space. Available at: http:// www.forestry.gov.uk/pdf/Making_woods_more_accessible.pdf/\$FILE/Making_woods_more_accessible.pdf (accessed: 20/10/2016)

BfN Bundesamt für Naturschutz. NaturSportInfo. Available at: natursportinfo.bfn.de/ (accessed: 20/07/2016). [In German]

Brown, G. \& D. Weber 2011. Public participation GIS a new method for national park planning. Landscape and Urban Planning 102(1): 1-15.

Brown, G. \& M. Kyttä 2014. Key issues and research priorities for public participation GIS (PPGIS): A synthesis based on empirical research. Applied Geography 46: 122-136.

Candrea, A. \& A. Ispas 2009. Visitor management, a tool for sustainable tourism development in protected areas. Bulletin of the Transilvania University of Braslov 2(51) Series V: Economic Sciences: 131-136.

CEAA Canadian Environmental Assessment Agency 2016. Public Participation Guide. Available at: https://www.ceaa-acee.gc.ca/ d e fault.as p ? l ang $=E n \& n=46425 \mathrm{CA} \mathrm{F}$ 1\&offset $=7 \&$ toc $=$ hide\#p1-7 (accessed: 30/01/2017).

Coleman, D.J., Y. Georgiadou \& J. Labonte 2009. Volunteered Geographic Information: The Nature and Motivation of Produsers. IJSDIR 4: 332-358.
Dörrzapf, L., M. Wasserburger, W. Wasserburger \& S. Hennig 2015. SenTOUR - seniorengerechte Aufbereitung von Geoinformationen im Bereich des alpinen Tourismus. AGIT Journal 1-2015: 510-516. [In German]

Elands, B. et al. 2014. Atlantic Region. In: Pröbstl, U., V. Wirth, B. Elands \& S. Bell. (eds.), Management of Recreation and Nature Based Tourism in European Forests: 11-48. Heidelberg.

Elwood, S., M.F. Goodchild \& D.Z. Sui 2012. Researching volunteered geographic information: Spatial data, geographic research, and new social practice. Ann. Assoc. Am. Geogr. 102: 571-590.

Engels, B. 2015. Citizen Science: An overview of the current state, the possibilities and challenges and the opportunities for the future. Walter.

Haklay, M. 2010. How good is volunteered geographical information? A comparative study on OpenStreetMap and Ordnance Survey datasets. Environment and Planning b: Planning and Design 37: 682-703.

Hennig, S., A. Ostenberger, J. Neuschmid, W. Wasserburger \& M. Schrenk 2012. Providing Web Maps for Everyone. Understanding Users and their Requirements. Proceedings CORP 2012: 627-635. Schwechard.

Hennig, S. \& J. Pfeifer 2011. Infrastrukturen als innovative Maßnahme im Schutzgebietsmanagement. Natur und Landschaft 8: 355-362. [In German]

Hennig, S. \& M. Künzl 2016. Applying Integrated Nature Conservation Management: Using visitor management and monitoring to handle conflicts between winter recreation and grouse species in Berchtesgaden National Park. In: Georgiev, G. (ed.), Sustainable development in the mountain region. Southeastern Europe: 319-334. Heidelberg.

Herfort, B., M. Eckle, P. Porto de Albuquerque \& A. Zipf 2015. Towards assessing the quality of volunteered geographic information from OpenStreetMap for identifying critical infrastructure. Proceedings ISCRAM 2015, Kristiansand.

IUCN International Union for Conservation of Nature 2008. Guidelines for Applying Protected Area Management Categories. IUCN. Gland.

Job, H., D. Metzler \& L. Vogt 2003. Inwertsetzung alpiner Schutzgebiete. Eine regionalwirtschaftliche Analyse des Tourismus im Alpenpark Berchtesgaden. Münchner Studien zur Sozial-/ Wirtschaftsgeographie 43. [In German]

Loidl, M. \& S. Keller 2015. An intrinsic approach for the detection and correction of attributive inconsistencies and semantic heterogeneity in OSM data. Presentation at AAG Annual Meeting, Chicago.

Loidl, M., S. Krampe, B. Zagel \& G. Pucher 2014. Aufbereitung von Open Street Map Daten für GISModellierungen und Analysen. In: Strobl, J., T. Blaschke, G. Griesebner \& B. Zagel (eds.), AGIT 2014: 505514. Offenbach. [In German]

Lupp, G., M. Feuerstein, L. Heuchele \& W. Konold 2016. Trail use and perception of a diverse mountain farming landscape by hikers in the protected area All- 
gäuer Hochalpen in the German Alps. eco.mont 8(1): $21-28$

Monteiro, L. 2016. Using GPS data from Web 2.0 platforms to assess informal trail network and its impacts in protected areas. Proceedings MMV8, Novi Sad: 270-272.

Nationalpark Berchtesgaden 2006. Modell-Management-Plan zum Thema „Barrierefreibeit" am Beispiel des $\mathrm{Na}$ tionalparks Berchtesgaden. Berchtesgaden. [In German]

Nationalpark Berchtesgaden 2007. EuRegionales Erholungsgebiet Nationalpark Berchtesgaden / Salzburger Kalkhochalpen. Available at: http:/ /www. nationalpark-berchtesgaden.bayern.de/nationalpark/ forschung/abgeschlossen/euregio.htm (accessed: 20/04/2016) [In German]

Newsome, D., S. Moore \& R. Dowling 2001. Natural Area Tourism. Ecology, Impacts and Management. Clevedon.

OECD Organization for Economic Co-operation and Development 2007. Participative Web: User-Created Content. OECD. Paris.

OSM$^{1}$. OpenStreetmap Wiki. Available at: http:// wiki.openstreetmap.org (accessed: 20/7/2016).

$\mathrm{OSM}^{2}$. Proposal Process. Available at: http://wiki. openstreetmap.org/wiki/Proposal_process (accessed: 20/07/2016).

$\mathrm{OSM}^{3}$. Quality assurance. Available at: http:// wiki.openstreetmap.org/wiki/Quality_assurance (accessed: 08/12/2016).

Preuss, J. 2005. Management von Natura 2000 Arten am Beispiel der Raufußhübner im Nationalpark Berchtesgaden. Diplomarbeit. Weihenstephan. [In German]

Quinn, S. \& J.A. Dutton 2014. OpenStreetMap and its use as open data. Available at: https://www.eeducation.psu.edu/geog585/node/738 (accessed: 20/07/2016).

Türk, S. \& F. Wölfel 2016. Barrier-free nature experience in national parks - Evaluation of visitor guidance through experience engineering. Proceedings MMV8, Novi Sad: 212-213.

van den Berg, C., F. van Bree \& S. Cottrell 2004. PAN Parks implementation process: cross cultural comparison - Bieszczady \& Slovenski Raji National Parks. Proceedings $M M V$ 2, Rovaniemi. Available at: http://www.metla.fi/julkaisut/workingpapers/2004/ mwp002.htm (accessed: 20/07/2016).

Vogler, R. 2015. „Soziale Geokommunikation“ durch GI-Laien: (k)eine Frage des Webmapping Tools? In: Hennig, S. (ed.), Online Karten im Fokus: 105-124. Berlin. [In German]

Walden-Schreiner, C. \& Y. Leung 2016. Incorporating the digital footprints of visitors in protected areas and impact monitoring: Case studies from the USA and Australia. Proceedings MMV8, Novi Sad: 274-276.

Wasserburger, W, C. Beyer, S. Hennig \& M. Wasserburger 2106. Seniorengerechte Kommunikation von Geoinformationen in Nationalparks am Beispiel senTOUR. Proceedings Real CORP 2016, Hamburg: 931-936. [In German]
Willis, J., B. Weiser \& D. Kitkwood 2014. Bridging the Gap: Meeting the Needs of Early Childhood Students by Integrating Technology and Environmental Education. International Journal of Early Childhood Environmental Education 2(1): 140-155.

Worboys, G.L., M. Lockwood \& T. De Lacy 2005. Protected Area Management. Oxford.

Zelenka, J. \& J. Kaceti 2013. Visitor management in protected areas. Czech Journal of Tourism 2(1): 5-18.

\section{Glossary}

\section{GIS (Geographic Information System)}

A GIS is a computer-based tool which allows users to analyse, store, manipulate and visualize geographic data on a map in order to understand spatial relationships, patterns and trends.

\section{GPS (Global Position System)}

GPS is a global navigation satellite system (GNSS) which is made up of a network of satellites placed into orbit by the U.S. Department of Defense. Originally intended for military applications, the U.S. government made GPS available for civilian use. It provides geolocation and time information to a GPS receiver in all weather conditions, anywhere on or near the Earth where there is an unobstructed line of sight to four or more GPS satellites.

\section{OSM (OpenStreetMap)}

OSM is a project as well as an online platform to create a free, editable map of the world (www. openstreetmap.org). Since anyone is allowed to add data to the OSM database, OSM data is considered to be volunteered geographic information. OSM is currently the largest community-based collection of spatial data.

\section{PPGIS (Public Participation GIS)}

PPGIS is aimed at bringing the academic practices of GIS and mapping to the local general public. It supports knowledge production by local people and non-governmental groups. Application areas include community and neighbourhood planning, and environmental and natural resource management.

\section{Spatial literacy}

This term refers to digital competencies as well as to skills enabling users to communicate via spatial data products, create their own spatial data products, and critically reflect on these products. In society, these competencies are still largely lacking. The literature stresses the relevance of educational measures to improve digital and spatial literacy.

\section{Tags}

OSM data elements (nodes, ways and relations) are described using tags. Tags consist of a key and a value (form key=value; e.g. amenity=parking). The OSM com- 
munity has agreed on certain key and value combinations, which serve as informal standards.

\section{UGC (User Generated Content)}

UGC refers to any kind of content, such as blogs and forums, wikis, posts, chats, tweets, podcasts, photos, videos and audio files, created by users of an online system or service. Often, this content is made available via social media websites.

\section{VGI (Volunteered Geographic Information)}

VGI is the use of tools to create, assemble and disseminate geographic data that is provided voluntarily by users of the tools. VGI is a special case of usergenerated content. An example of a tool is OpenStreetMap.

\section{Author}

\section{Sabine Hennig}

After having graduated in geography, Sabine Hennig completed a PhD at University of Salzburg, in Applied Geoinformatics. She is currently working in the Department of Geoinformatics-Z_GIS, University of Salzburg. Her research interests are, among others, in the area of participatory GI approaches. Interfaculty Department of Geoinformatics-Z_GIS, University of Salzburg. Schillerstr. 30, 5020 Salzburg, Austria. Email: sabine.hennig@sbg.ac.at 